\title{
Daria Rutecka
}

Uniwersytet Mikołaja Kopernika, Torun

ruteckadaria@gmail.com; ORCID: 0000-0003-3469-4496

\section{Right to reprint in the Internet age}

http://dx.doi.org/10.12775/SIT.2018.016

Unlike the right to a quotation, the right to reprint ${ }^{1}$ may be held only by specific entities, enlisted in relevant legal acts. For instance, in Poland, issues related to the right to reprint are regulated by the Press Law (dated 26 January 1985) and the Copyright Act (dated 4 February 1994), while in the United States the Constitution and the Copyright Law (dated 30 June 2016 and including all amendments made to its previous versions) is extensively accompanied by the case law. In general, the right to reprint is described as a form of fair use (or "fair dealing" in some countries ${ }^{2}$ ) of copyrighted materials and consists in a distribution of such materials which were already published. The distribution may take place provided that it is made for information purposes.

As already indicated, not everyone is entitled to take advantage of the right to reprint. As a rule, under Polish law, this right applies only to the professional entities, such as press, radio and television (generally understood as "mass media") ${ }^{3}$. Even though lawmakers in the entire world are trying to follow the technological

\footnotetext{
${ }^{1}$ Depending on the source, other possible wordings include e.g. "reproduction".

2 J. Band, J. Gerafi, The Fair Use/Fair Dealing Handbook, March 2013, available at: http://infojustice.org/wp-content/uploads/2013/03/band-and-gerafi-2013.pdf (access: 2.07.2018)

${ }^{3}$ P. Ślęzak, w: Ustawa o prawie autorskim i prawach pokrewnych. Komentarz, red. P. Ślęzak, Warszawa 2017, komentarz do art. 25, teza/item II.2.
} 
development and adjust the existing laws to the constantly changing reality, it is still difficult to redefine certain ideas in order to properly acknowledge the impact the Internet has made on them. One of those definitions which remain misleading and may lead to many uncertainties is the definition of press. Most of the wellknown newspapers have nowadays their online editions. Although the Internet surely cannot be defined as a "press" itself, it must be remembered that its certain contents fall within this category ${ }^{4}$ and cannot be excluded from the right to reprint application. The above shows that since the catalogue of entities allowed to reprint is a closed one, it is crucial to determine which entities and under what circumstances are entitled to reprint.

On the other hand, everyone everywhere is entitled to quote parts of works which have already been published elsewhere, in other works constituting an independent whole. The quotation must be justified its purpose: explanations, discussions, critical or scientific analyses, teaching or rules governing a specific type of creative activity. Therefore, the development of technology, especially the Internet, may not affect the rules regulating the right to quotation.

\section{General information}

According to the Berne Convention dated 9 September 1886, the right to reprint should be regulated on a national level in each country. To cite its exact wording: "It shall also be a matter for legislation in the countries of the Union to determine the conditions under which lectures, addresses and other works of the same nature which are delivered in public may be reproduced by the press, broadcast, communicated to the public by wire and made the subject of public communication [...], when such use is justified by the informatory purpose." Accordingly, under Polish law only the information purposes may justify the reprinting made in

${ }^{4}$ G. Pacek, Wykorzystywanie przez prasę utworów chronionych prawem autorskim. Wyjątki, wyłączenia i ograniczenia, Warszawa 2015, p. 300. 
press, radio or television ${ }^{5}$. Moreover, only strictly specified categories of works fall within the scope of the discussed provisions. These include works which have already been broadcasted: (I) reports on current events, (II) articles on current political, economic or religious issues, (III) current comments made and photographs taken by reporters, as well as short excerpts from the abovementioned reports and articles, reviews of publications and disseminated works, and short summaries of a disseminated work.

Likewise, the Directive 2001/29/EC of the European Parliament and of the Council of 22 May 2001 on the harmonisation of certain aspects of copyright and related rights in the information society (hereinafter referred to as "the Directive") also provides for a similar exception for fair use. According to the Directive, Member States are allowed to adopt certain limitations on the right to reproduction, e.g. for press usage ${ }^{6}$.

\section{Scope of the right to reprint}

Coming back to the reprinting objective, it must be emphasized that the "information purposes", as specified in all provisions on reprint, are not easy to define. For instance, information purposes must be distinguished from objectives such as entertainment, education or science, even though it may seem like all of the above involve the "information" element ${ }^{7}$. In order for the reprinting to be legal, its purpose has to be clear and unambiguous. However, most of the time it is very difficult to achieve. It is accepted in Polish doctrine

5 „Journal of Laws” of 1994 No 24, item 83 with amendments, Art. 25 sec. 1.

${ }^{6}$ Directive 2001/29/EC of the European Parliament and of the Council of 22 May 2001 on the harmonization of certain aspects of copyright and related rights in the information society, Art. 5 sec. 3 item c; L. Guibault, G. Westkamp, T. Rieber-Mohn, Study on the implementation and effect in Member States' laws of directive 2001/29/EC on the harmonisation of certain aspects of copyright and related rights in the information society, Amsterdam 2007, p. 52.

7 S. Stanisławska-Kloc, in: Prawo autorskie i prawa pokrewne, D. Flisak (ed.), Warszawa 2015, komentarz do art. 25, p. 393. 
that for example the purpose of publishing the summaries of school essential reading books cannot be considered as "information".

Even the wording of the Directive seems to be equally general and brief when it comes to the matter of reasons to reprint. Reprinting made by the press is allowed only "to the extent justified by the informatory purpose [...]" 9 . Therefore, it is essential to determine what should be treated as "information" and "information purpose". The lawmakers definitely aimed at the protection of free flow of information and press. How to determine what publication is covered by the discussed provisions, though?

The real problem occurs when except for the information one, certain materials are being reprinted also for other purposes. Additionally, it goes without saying that every day newspapers and news portals are providing their recipients with several kinds of information and materials: there are publications concerning serious political matters, issues relevant on both global and national level, but there are also publications on more frivolous and trivial issues such as articles or interviews with celebrities, sensational events etc. It appears that the exact content and quality of materials does not matter as long as the purpose of its publication is purely informative.

It is said that the so called "infotainment" has been replacing other news (e.g. concerning public affairs) for years ${ }^{10}$. "Infotainment" is a pejorative name for a combination of news that is both of informatory and entertainment nature and aims at attracting viewers or readers ${ }^{11}$. The issue with the "infotainment" is that it does indeed serve and informatory purpose. However, its main goal is to shock or entertain the recipient.

The "infotainment" was subject to some controversy all over the world. Back in 2002 one of the Australian courts decided that broadcasting copyrighted material for entertainment (and not only

8 Ibidem.

9 Directive 2001/29/EC of the European Parliament and of the Council of 22 May 2001 on the harmonization of certain aspects of copyright and related rights in the information society, Art. 5 sec. 3 item c.

${ }_{10}$ W.A. Hachten, The Troubles of Journalism, New Jersey 2005, p. 74.

11 P.D. Schulz, Courts, The Media and Infotainment: A Discourse of Disrespect?, April 14, 2012. 
informative) purposes does not constitute a fair dealing and, therefore, is illegal. The decision was widely criticized due to the limiting approach to the freedom of creating television. Nowadays, the "infotainment" is inevitable, especially on the Internet. According to the research conducted already in 2012, the boundaries between a pure information, journalism and entertainment are blurring. The research was based on leading Polish online information portals: tvn24.pl and tvp.info and produced interesting results, namely the analytical language and style of writing was replaced with a more narrative reporting, the topics presented and discussed had become more superficial and shallow ${ }^{12}$. What is more, online information portals place serious contents right next to entertainment ones ${ }^{13}$, which as it seems may cause misunderstandings and lead to subsequent misinterpretations. Surely, the informative purpose should be defined more precisely in order to avoid doubts as to whether or not certain use of copyrighted materials for informative but also other purposes (e.g. entertainment) is legal.

However, currently under Polish law there is not enough solid arguments not to treat "infotainment" as some kind of information. Since the Polish legislator allowed to broadcast certain copyrighted materials for informatory purposes, and did not specifically restrict it to "only informatory purposes", it should be concluded that as long as there is any informatory purpose (even if accompanied by another purpose for broadcasting, e.g. entertainment), the requirement is met.

\section{Is press the only one entitled to reprinting? Issues with the "press" definition}

Under previously existing provisions the issue was pretty clear - the press was entitled to take use of the reprinting rights, and since the legal act was in force from 1952 till 1994, the issue of the rapid Internet development was not a big deal back then. Nowadays, it

12 A. Naruszewicz-Duchlińska, Inforozrywka (infotainment) $w$ portalach informacyjnych tun24.pl i tvp.info, Olsztyn 2013, p. 65.

13 Ibidem, p. 67. 
is not so easy to explicitly determine which entities are and which are not considered press ${ }^{14}$.

The legal position of press is presently vague and even though certain legal acts attempt to define it, the popularity of the Internet seems to undermine those attempts. In order to present this issue in more detail, the current Polish press definition should be recalled and briefly explained. And so, the Polish Press law defines press as periodical publications that do not form a single and complete whole, which are published at least once a year and have a constant title or name, a number and a date ${ }^{15}$. Significantly, the same provision stipulates that any already existing and future (created thanks to the technological development) mass media distributing periodical publications through print, vision, sound or any other distribution technique ${ }^{16}$. Where lies the problem then?

According to Grzegorz Pacek, the Polish legislator remains hugely inconsistent in treating and defining on-line publications as "press"17, which consequently may lead to uncertainties. On the one hand, the definition of press (as regulated in the Press Law) mentioned above, should be considered as the lead one. On the other hand, however, there are many legal acts in which the lawmaker seems to ignore certain elements of the definition from the Press Law and does not refer to it at all. Namely, the Polish act on natural persons' income tax exempts from income tax the value of prize won in contests organized in press, radio and television. Since it does not make any reference to the "main" definition from the Press Law, relying merely on the literal interpretation of this provision could lead to an erroneous conclusion that prizes won in any contest organized on the Internet, is not covered by the exemption. Even though it may seem like the discussed provision is not of crucial importance, its vague wording has already caused a number of

${ }^{14} \mathrm{~K}$. Gienas, in: Ustawa o prawie autorskim i prawach pokrewnych. Komentarz, E. Ferenc-Szydełko (ed.), Warszawa 2016.

15 (“Journal of Laws” of 1984 No 5, item 24 with amendments, Art. 7 Sec. 2 item 1.

16 Ibidem.

17 G. Pacek, op.cit., p. 308. 
misunderstandings and was considered not only by local courts, but also the Ministry of Finance and the Supreme Administrative Court of Poland. In 2016, the administrative court in Warsaw decided that the Ministry of Finance was wrong by stating that prizes won in competitions organized by companies through the Internet are not covered by the exemption. The case was further referred to the Supreme Administrative Court, which finally explained that prizes won in a contest organized on the Internet are subject to the exemption only if the contest was organized by a "mass media entity". The court clarified that a mass media entity provides professional services consisting of transmitting various contents to an unspecified audience. Additionally, it mentioned that the legislator has already indicated examples of mass media entities, i.e. press, radio and television. Such examples of the Internet mass media are the owners of online magazines (newspapers), radio and television ${ }^{18}$.

Interestingly, back in 2012 in a different case, the Ministry of Finance declared that online social networks, such as Facebook, cannot be regarded as mass media and, therefore, contests organized by those networks are not covered by the exemption form the income tax act ${ }^{19}$. Consequently, this leads to a rather complicated conclusion that Facebook itself cannot be treated as press but what about certain contents that are posted on the platform? Nowadays magazines and papers not only have their own websites and online versions but most likely also a Facebook page. Based on some views presented in the doctrine and case law so far, it would seem that as long as the entity running a Facebook page falls within the category of press, it is allowed to take advantage of the fair use of copyrighted material.

Some Polish lawyers argue that an online information portal should be treated as press if only it can be characterized as "periodical" 20 and published regularly ${ }^{21}$. Nevertheless, the defini-

18 Wyrok NSA z dnia 4 lutego 2016 r., II FSK 3140/13, Legalis nr 1408414.

19 Interpretacja indywidualna $z$ dnia 14 czerwca 2012 r., DD3/033/221/ /OBQ/10/PK-1500; J. Marciniuk (ed.), Podatek dochodowy od osób fizycznych. Komentarz, Warszawa 2017, komentarz do art. 21, teza/item 2.

${ }^{20}$ P. Ślęzak, op.cit., komentarz do art. 25, teza/item III.B.2.

${ }^{21}$ J. Barta, R. Markiewicz (eds.), Prawo mediów, Warszawa 2008, p. 202. 
tion of press cannot be extended to websites the content of which changes very rarely (e.g. companies' websites) ${ }^{22}$.

However, moving back to the reprinting issue itself, it is crucial to keep in mind Article 25 sec. 4 of the Polish Copyright Act, which states that the provisions on reprinting as regarding press, radio and television should be applied accordingly to copyrighted materials made publicly available in a way which allows everyone to access them anytime and anywhere ${ }^{23}$. Even though according to the ratio legis of the amendment which introduced section 4 back in 2004, section 4 was supposed to make Internet broadcasting more convenient ${ }^{24}$, it only led to ambiguities and created controversies.

For instance, according to Elżbieta Traple the wording of Art. 25 sec. 4 of the Copyright Act provides at least two possible answers and doubts at the same time as to who is covered by the right to reprint. In line with the discussed point of view it could be argued that the right to reprint applies not only to professional entities, but also to all and any entities operating on the Internet, as long as they make certain copyrighted materials publicly available pursuant to Art. 25 of the Copyright Act ${ }^{25}$. Part of the doctrine states that this opinion, stays in conflict with the literal wording of the discussed article, as well as article $5 \mathrm{sec} .3$ item c of the Directive, as the European legislator only allows for reprinting done by professional entities (therefore, press) ${ }^{26}$. Both opinions have their followers. The issue is even more compounded by the rather controversial opinion of Advocate General Vericy Trstenjak who in 2009 stated that press may mean only traditional newspapers ${ }^{27}$.

${ }^{22}$ P. Ślęzak, op.cit., teza/item III.B.2.

23 "Journal of Laws" of 1994 No 24, item 83 with amendments.

${ }^{24}$ Uzasadnienie do projektu ustawy o zmianie ustawy o prawie autorskim $i$ prawach pokrewnych wraz $z$ projektami podstawowych aktów wykonawczych, Sejm Rzeczypospolitej Polskiej, IV kadencja, Druk nr 2465, Warszawa, 19 stycznia 2004 r.; R. Golat, Prawo autorskie. Komentarz dla praktyków, Gdańsk 2008, p. 90.

${ }^{25}$ J. Barta, R. Markiewicz, Prawo autorskie i prawa pokrewne, Warszawa 2017, p. 119.

${ }^{26}$ P. Ślęzak, op.cit., teza/item III.B.4.

27 Opinion of Advocate General Vericy Trstenjak delivered on 12 February 2009, case C-5/08, item 118. 
Another problematic issue concerns on-line blogs. Currently, the Polish doctrine is divided as to whether they can or cannot be treated as press. According to the Province Administrative Court in Warsaw, as long as someone creates, prepares and writes their materials on their own, and takes care of publishing them, such person is performing three functions enumerated in the press law: a journalist, editor and editor-in-chief. Therefore, a blogger and consequently, his or her blog, should be treated as press ${ }^{28}$. Similar point of view is presented by some representatives of the doctrine, as well. Pursuant to those views, in order to consider certain portal to be "press", one must take into consideration the purpose of creating such portal. If it is purely informative, we deal with press. However, not everyone agrees with the presented opinion $^{29}$. When it comes to blogs, the same judgment of the Province Administrative Court in Warsaw as mentioned above stipulates that not everything which was created as a result of technological development and aims at unlimited audience, can be considered as press. Once again, the purpose is of the essence. Unfortunately, determining the purpose of creating a blog may sometimes create considerable difficulties. That is why at the moment it cannot be stated unambiguously whether blogs are or are not press. Since this matter is not explained in legal provisions, any views presented in the doctrine are just personal views of their authors. Even though it may seem like the topic is insignificant, if a blogger wants to take use of the right to reprint or aspires to become a part of the press, he or she would be obliged to register their blog (if it is a journal or magazine covered by the scope of the "press" definition) ${ }^{30}$. Failure to do so may result in financial fines, which may be quite burdensome for a person who runs their blog on their own. Evidently, Polish lawmaker is not the only one in the world to which creating a clear

28 Postanowienie WSA w Warszawie z dnia 30 października 2008 r., II SA/ /Wa 1885/07, Legalis nr 298112.

${ }^{29}$ E. Traple, Raport na temat dostosowania polskiego systemu praw autorskich i praw pokrewnych do wymogów społeczeństwa informacyjnego, Warszawa-Kraków 2012, p. 19.

${ }^{30}$ G. Kuczyński (ed.), Prawo prasowe. Komentarz, Warszawa 2012, teza/ /item I.2. 
and unambiguous definition of a blog causes problems, and which did not categorize blogs sufficiently enough. For instance, as shown in a landmark case of the Supreme Court of the United States of America - Citizens United v. Federal Election Commission ${ }^{31}$, the distinction between institutional press and other speakers (such as bloggers) does not work well in practice. The court ruled in the case at hand that "with the advent of the Internet and the decline of print and broadcast media, moreover, the line between the media and others who wish to comment on political and social issues becomes far more blurred." 32 The above perfectly demonstrates that with the ongoing digitalization and popularity of Internet, it gets more difficult to distinguish bloggers from press.

Currently, there are still a lot of misunderstandings and uncertainties considering the Polish definition of press and the use of right to reprint. Assuming that the Polish legislator acted rationally, adding section 4 was supposed to have a different scope of application than preceding sections and, therefore, it can be argued that a creator of Internet website does not have to be considered press in order to have the right to reprint. Including bloggers as entities entitled to reprint (reproduction) could be less burdensome if the Polish regulation did not refer to the definition of "press" directly, as it is in case of $\S 107$ of the American Copyright Law stating "[...] the fair use of a copyrighted work, including such use by reproduction in copies or phonorecords or by any other means specified by that section, for purposes such as criticism, comment, news reporting, teaching (including multiple copies for classroom use), scholarship, or research, is not an infringement of copyright ${ }^{33}$ ". It must be remembered, though, that the American doctrine relies heavily on the case las, as well. Therefore, the Polish approach should be

${ }^{31}$ Citizens United v. Federal Election Commission, opinion of the Supreme Court of the United States of America dated 21 January 2010, 558 U.S. 310 (2010), 130 S. Ct. 876; 175 L. Ed. 2d 753; 2010 U.S. LEXIS 766, available at: https://www.law.cornell.edu/supct/html/08-205.ZO.html (access: 28.06.2018)

32 Ibidem, item 1, par. 8.

${ }^{33}$ Title 17 of the United States Code, Copyright Law of the United States, Circular 92, par. 107. 
adjusted accordingly, and any future amendments and regulations must be as precise as possible.

As the issue at hand is currently very unclear, it seems like certain de lege ferenda postulates should be made. Firstly, the legal position of blogs should be clarified, at least at a national level. Secondly, the Polish legislator should provide certainty as to who may benefit from the right to reprint. In order to do so, in line with Elżbieta Traple's views, certain clarifications should be made as to what kind of Internet portals in particular may either be treated as press or be entitled to reprint as such ${ }^{34}$. An exhaustive and explicit list of entities, portals or websites which fall within the category of press could be one of the possible ways to achieve the above. Such list, however, would require regular updates in order to fully reflect the constant changes occurring in the Internet-related trends.

\section{STRESZCZENIE}

Prawo do przedruku w dobie Internetu

Niniejszy artykuł porusza tematykę prawa do przedruku, zwłaszcza w odniesieniu do podmiotów działających w Internecie. Głównym przedmiotem rozważań jest kwestia ustalenia podmiotów uprawnionych zgodnie $z$ art. 25 ustawy o prawie autorskim i prawach pokrewnych. Artykuł omawia problem związany z definicją prasy oraz sytuacją prawną blogów.

Słowa kluczowe: przedruk; prasa; prawa; autorskie

\section{SUMMARY}

Right to reprint in the Internet age

This article covers the topic of reprinting rights, especially in relations to entities operating on the Internet. The main subject of analysis is the issue of determining which entities are entitled pursuant to Article 25 of

${ }^{34}$ E. Traple, op.cit., p. 19. 
the Polish Copyright Act. The article concerns the matters relating to the definition of press and legal situation of blogs.

Keywords: reprint; reproduction; press; copyright

\section{BIBLIOGRAPHY}

Band J., Gerafi J., The Fair Use/Fair Dealing Handbook, March 2013, available at: http://infojustice.org/wp-content/uploads/2013/03/ band-and-gerafi-2013.pdf (access: 02.07.2018).

Barta J., Markiewicz R. (eds.), Prawo mediów, Warszawa 2008.

Barta J., Markiewicz R., Prawo autorskie i prawa pokrewne, Warszawa 2017

Gienas K., w: Ustawa o prawie autorskim i prawach pokrewnych. Komentarz, red. E. Ferenc-Szydełko, wyd. 3, Warszawa 2016.

Golat R., Prawo autorskie. Komentarz dla praktyków, Gdańsk 2008.

Guibault L., Rieber-Mohn T., Westkamp G., Study on the implementation and effect in Member States' laws of directive 2001/29/EC on the harmonisation of certain aspects of copyright and related rights in the information society, Amsterdam 2007.

Hachten W.A., The Troubles of Journalism, New Jersey 2005.

Kuczyński G. (ed.), Prawo prasowe. Komentarz, wyd. 2, Warszawa 2012.

Marciniuk J. (ed.), Podatek dochodowy od osób fizycznych. Komentarz, wyd. 18, Warszawa 2017.

Naruszewicz-Duchlińska A., Inforozrywka (infotainment) $w$ portalach informacyjnych tun24.pl i tvp.info, Olsztyn 2013.

Pacek G., Wykorzystywanie przez prasę utworów chronionych prawem autorskim. Wyjątki, wyłaczenia i ograniczenia, Warszawa 2015.

Schulz P.D., Courts, The Media and Infotainment: A Discourse of Disrespect?, (April 14, 2012), Australian Institute of Judicial Adminstration joint project with Canberra University, Australia 2012.

Stanisławska-Kloc S., w: Prawo autorskie i prawa pokrewne, D. Flisak (ed.), Warszawa 2015.

Ślęzak P., Ustawa o prawie autorskim i prawach pokrewnych. Komentarz, P. Ślęzak (ed.), Warszawa 2017.

Traple E., Raport na temat dostosowania polskiego systemu praw autorskich i praw pokrewnych do wymogów społeczeństwa informacyjnego, Warszawa-Kraków 2012. 